JPSCR: Journal of Pharmaceutical Science and Clinical Research, 2021, 01, 12-19

DOI: $10.20961 /$ jpscr.v6i1.41924

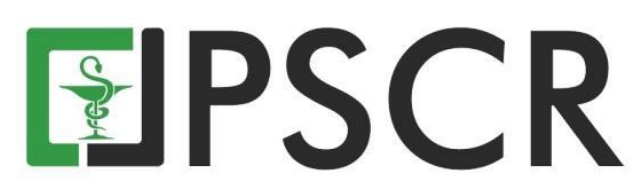

\title{
Analisis Kesintasan Laju Kejadian Hipertensi Berdasarkan Perbedaan Usia Akseptor Kontrasepsi Oral
}

\section{Nurmainah Nurmainah* dan Nur Alfan}

Departemen Farmakologi dan Farmasi Klinik, Program Studi Farmasi, Universitas Tanjungpura, Jl. Prof. Dr. H. Hadari Nawawi, Pontianak, Indonesia 78124

*email korespondensi: nurmainah@ pharm.untan.ac.id

Received 2 June 2020, Accepted 11 January 2020, Published 15 March 2021

\begin{abstract}
Abstrak: Peningkatan tekanan darah pada akseptor kontrasepsi oral dipengaruhi oleh perbedaan usia. Tujuan dari penelitian ini untuk mengkaji risiko dan laju kejadian hipertensi berdasarkan perbedaan usia akseptor kontrasepsi oral. Metode penelitian bersifat analitik observasional dengan rancangan studi kohort retrospektif. Penelitian dilakukan dengan pengumpulan basis data akseptor yang menggunakan kontrasepsi oral di Puskesmas Perumnas II, Pontianak. Data yang digunakan adalah data akseptor baru yang menggunakan kontrasepsi oral selama Januari hingga Desember 2017. Periode ini merupakan tanggal indeks penggunaan kontrasepsi atau tanggal dimulainya penggunaan kontrasepsi oral pertama kali oleh akseptor. Perjalanan penggunaan kontrasepsi oral oleh akseptor diikuti sampai akhir penelitian (30 Oktober 2019). Akhir pengumpulan data penelitian dikelompokkan menjadi kelompok usia $\leq$ 30 tahun dan kelompok usia >30 tahun dengan menganalisis risiko dan laju kejadian hipertensi. Teknik pengambilan sampel yang digunakan dalam penelitian ini adalah teknik purposive sampling. Pengambilan data dilakukan berdasarkan kriteria inklusi dan ekslusi. Data akseptor yang memenuhi kriteria inklusi dan ekslusi sebanyak 75 orang. Data yang diperoleh dianalisis dengan uji khi kuadrat, analisis Kaplan-Meier, cox proportion hazard test, dan uji t. Hasil penelitian menunjukkan bahwa kelompok usia >30 tahun berisiko 3,376 kali lebih besar mengalami kejadian hipertensi dibandingkan kelompok usia $\leq 30$ tahun $(p=0,016 ; R R=3,376$; CI 95\%=1,085-10,50). Laju kejadian hipertensi pada kelompok akseptor dengan usia $>30$ tahun lebih cepat 4,045 kali dibandingkan dengan kelompok akseptor yang berusia $\leq 30$ tahun $(\mathrm{HR}=4,045$; CI $95 \%=1,18-13,88)$. Kesimpulan dari penelitian ini adalah usia akseptor $>30$ tahun memiliki laju kejadian hipertensinya lebih cepat dibandingkan akseptor dengan usia $\leq 30$ tahun.
\end{abstract}

Kata Kunci: akseptor; kontrasepsi oral; usia; kejadian hipertensi.

Abstract: Survival Analysis for the Incidence Rate of Hypertension Based on Age Differences in Contraceptive Oral. Blood pressure increased in the oral contraceptive acceptor is influenced by age differences. The study aimed to analyze the risk and rate of hypertension incidence based on the age difference of the oral contraceptive acceptor. The research method was observational analytic with a retrospective cohort study design. The study has collected a database of acceptors using oral contraceptives in Perumnas II Health Center, Pontianak. The data were obtained from new acceptors using oral contraceptives from January to December 2017. This period was the date of the index of contraceptive use or the first data used of oral contraceptives. The course of oral contraceptive use by acceptors has followed until the end of the study (30 October 2019). Acceptors were divided into two groups, the age group $\leq 30$ years and the age group $>30$ years, which identifies the relationship and the incidence of hypertension. The sampling technique used in this study was a purposive sample. Data was collected based on inclusion and exclusion criteria, of which 75 acceptor data are meet the inclusion and exclusion criteria. Data analyzed by Chi-square test, Kaplan-Meier analysis, cox 
proportion hazard test, and t-test. The results showed that those who were the age of the acceptor $>30$ years had a risk of 3,376 times greater risk of developing hypertension than those aged $\leq 30$ years $(\mathrm{p}=0.016 ; \mathrm{RR}=3.376 ;$ CI $95 \%=1,085-10.50)$. The incidence of hypertension in the acceptor group with age $>30$ years was 4.045 times faster than the acceptor group aged $\leq 30$ years $(\mathrm{HR}=4.045 ; 95 \% \mathrm{CI}=1.18-13.88)$. The conclusion was the age of acceptors $>30$ years have hypertension incidence rate compared to acceptors with age $\leq 30$ years.

Key words: acceptors, age, incidence of hypertension, oral contraceptive

\section{Pendahuluan}

Kontrasepsi hormonal masih menjadi pilihan bagi wanita usia subur (WUS) di Indonesia. Hasil Riset Kesehatan Dasar (Riskesdas) tahun 2013 menunjukkan 51,8\% WUS di Indonesia memilih menggunakan kontrasepsi hormonal (Kemenkes RI, 2013). Kontrasepsi oral merupakan salah satu metode kontrasepsi hormonal yang banyak dipilih oleh WUS. Alasan penggunaan kontrasepsi tersebut dikarenakan kehandalannya sudah terpecaya dalam mencegah kehamilan dan sederhana cara penggunaannya. Disisi lain, tingkat reversibilitasnya lebih tinggi dibandingkan kontrasepsi hormonal lainnya. Data Survei Demografi dan Kesehatan Indonesia (SDKI) 2017 menunjukkan bahwa penggunaan kontrasepsi oral di Indonesia menduduki peringkat kedua terbanyak setelah suntik KB dengan persentase sebesar 12,2\% (BKKBN, 2018). Pengguna kontrasepsi oral di Kalimantan Barat juga menduduki peringkat kedua tertinggi setelah suntik KB dengan persentase 26,4\% (Kemenkes RI, 2018).

Kepatuhan penggunaan kontrasepsi oral sangat diperlukan dalam rangka mencegah kehamilan (Kusuma et al., 2020). Disisi lain, penggunaannya diketahui berisiko untuk terjadinya peningkatan tekanan darah (Olatunji \& Soladoye, 2008; Septya et al., 2014). Beberapa penelitian menyimpulkan hal yang sama bahwa WUS yang menggunakan kontrasepsi oral berisiko untuk terjadinya peningkatan tekanan darah dibandingkan WUS yang tidak menggunakan kontrasepsi oral (Septya et al., 2014; Sudayasa, 2017; Tanti et al., 2013) Peningkatan tekanan darah terjadi karena adanya gangguan hormon estrogen dan progesteron dalam tubuh. Kondisi tersebut mempengaruhi hipertrofi jantung dan peningkatan respon presor angiotensin II dengan melibatkan jalur sistem renin angiotensin (Olatunji \& Soladoye, 2008). Salah faktor yang mempengaruhi peningkatan tekanan darah pada akseptor pengguna kontrasepsi oral adalah usia. Penggunaan kontrasepsi oral diketahui berisiko tinggi mengalami kejadian hipertensi pada saat usia 40 tahun atau lebih (Sepriandi et al., 2017). Penelitian lainnya menyatakan bahwa akseptor dengan rentang usia 20 tahun hingga 41 tahun sudah mulai mengalami peningkatan tekanan darah (Tanti et al., 2013). Namun demikian, hasil penelitian lainnya menyatakan bahwa tidak ada hubungan signifikan antara penggunaan kontrasepsi oral dengan peningkatan tekanan darah pada akseptor yang berusia di bawah 30 tahun (Azima \& Mousavi, 2017). 
Adanya perbedaan kejadian peningkatan tekanan darah pada akseptor yang menggunakan kontrasepsi oral dengan berbagai kelompok usia maka peneliti memandang penting untuk melihat perbedaan kejadian hipertensi pada akspetor pengguna kontrasepsi oral yang berusia atau sama dengan 30 tahun ( $\leq 30$ tahun) dan kelompok akseptor yang berusia di atas 30 tahun (> 30 tahun) dengan uji khi-kuadrat. Disisi lain, penelitian ini mengkaji laju kejadian hipertensi melalui uji kesintasan dengan menggunakan analisis Kaplan-Meier dan cox proportion hazard test, sedangkan perbedaan tekanan darah dari kedua kelompok usia menggunakan uji t. Inferensi atau penarikan kesimpulan dilihat dari nilai log-rank test, nilai $\mathrm{p}$, nilai hazard ratio (HR), dan Confidence Interval (CI) (Goel et al., 2010; Rich et al., 2010).

\section{Metode}

Penelitian ini termasuk penelitian analitik observasional dengan menggunakan rancangan studi kohort retrospektif. Studi kohort retrospektif dilakukan dengan mengikuti subjek sejak pertama terpapar faktor risiko kemudian diikuti hingga waktu tertentu. Penelitian dilakukan dengan pengumpulan basis data akseptor yang menggunakan kontrasepsi oral di Puskesmas Perumnas II Kota Pontianak. Data yang digunakan adalah data akseptor baru yang menggunakan kontrasepsi oral selama Januari hingga Desember 2017. Periode ini merupakan tanggal indeks penggunaan kontrasepsi atau tanggal dimulainya penggunaan kontrasepsi oral pertama kali oleh akseptor. Perjalanan penggunaan kontrasepsi oral oleh akseptor diikuti sampai akhir penelitian (30 Oktober 2019). Akseptor dikelompokkan berdasarkan 2 kelompok usia, yaitu kelompok usia $\leq 30$ tahun dan kelompok usia > 30 tahun dengan mengidentifikasi hubungan kejadian hipertensi. Kejadian hipertensi dilihat dari hasil pengukuran tekanan darah yang tercatat di rekam medik, dimana tekanan darah sistolik dan tekanan darah diastolik $\geq$ $140 / 90 \mathrm{mmHg}$.

Teknik pengambilan sampel yang digunakan dalam penelitian ini adalah teknik purposive sampling. Pengambilan data dilakukan berdasarkan kriteria inklusi dan ekslusi. Adapun kriteria inklusinya yaitu akseptor baru (belum pernah menggunakan alat kontrasepsi apapun selama enam bulan terakhir di Puskesmas Perumnas II Pontianak, akseptor memiliki usia 20 tahun atau lebih, tidak memiliki riwayat hipertensi, memiliki data rekam medik yang lengkap, meliputi nama akseptor, nomor rekam medik, alamat, umur, nama obat, waktu kunjungan, data tekanan darah, dan diagnosa penyakit). Kriteria ekslusinya adalah akseptor yang berpindahpindah tempat fasilitas kesehatan. Data akseptor yang memenuhi kriteria inklusi dan ekslusi sebanyak 75 orang. Data yang diperoleh dianalisis dengan uji khi kuadrat, analisis KaplanMeier dan cox proportion hazard test, dan uji t. Pengolahan data dianalisis dengan Statistical Package for the Social Sciences (SPSS) versi 25. 


\section{Hasil dan Pembahasan}

\subsection{Karakteristik Akseptor Kontrasepsi Oral}

Selama dilakukan observasi data hampir dua tahun lamanya (Januari 2017 hingga Oktober 2019) diperoleh karakteristik akseptor pengguna kontrasepsi oral seperti terlihat pada Tabel 1. Akseptor yang menggunakan kontrasepsi oral lebih banyak pada usia > 30 tahun sebanyak $62,67 \%$. Persentase lama penggunaan kontrasepsi oral pada akseptor yang di bawah satu tahun ( $<1$ tahun) dan di atas atau sama dengan satu tahun ( $\geq 1$ tahun) tidak jauh berbeda, secara berturut-turut sebesar $49,30 \%$ dan $50,70 \%$. Jenis kontrasepsi yang paling banyak digunakan adalah jenis kontrasepsi oral kombinasi, yaitu sekitar 54,7\%.

Tabel 1. Karakteristik Akseptor Kontrasepsi Oral di Puskesmas Perumnas II Kota Pontianak Selama Tahun 2017-2019 $(\mathrm{N}=75)$.

\begin{tabular}{ccc}
\hline Variabel & Jumlah & $\begin{array}{l}\text { Persentase } \\
(\boldsymbol{\%})\end{array}$ \\
\hline Usia & 47 & 62,67 \\
a. $>30$ tahun & 28 & 37,33 \\
b. $\leq 30$ tahun & & \\
\hline Lama Pemakaian & 37 & 49,30 \\
a. $\geq 1$ tahun & 38 & 50,70 \\
b. $<1$ tahun & & \\
\hline Jenis Kontrasepsi Oral & 41 & 54,7 \\
a. Kombinasi & 34 & 45,3 \\
b. Tunggal & & \\
\hline
\end{tabular}

\subsection{Hubungan Usia dengan Risiko Kejadian Hipertensi Pada Akseptor Kontrasepsi Oral}

Tampak pada Tabel 2 bahwa kejadian hipertensi cenderung terjadi pada usia akseptor $>30$ tahun sebanyak 36,2\% dibandingkan usia akseptor $\leq 30$ tahun (10,7\%). Akseptor yang berusia di atas 30 tahun memiliki risiko 3,376 kali lebih besar mengalami kejadian hipertensi dibandingkan dengan akseptor yang berusia di bawah atau sama dengan 30 tahun. Perbedaan kejadian hipertensi diantara dua kelompok secara statistik bermakna signifikan $(p=0,016$; $R R=3,376 ; C I 95 \%=1,085-10,50)$. Hal ini didukung oleh beberapa hasil penelitian lainnya bahwa pertambahan usia sangat mempengaruhi kejadian hipertensi pada akseptor pengguna kontrasepsi oral (Artiyaningrum, 2015; Mekonnen et al., 2015; Nurmaghfirawati, 2016; Pangaribuan \& Dina, 2015; White et al., 2015).

Bertambahnya usia akan meningkatkan reseptor beta estrogen ( $\beta$-ER) (Harvey et al., 2016). Dengan adanya pemakaian kontrasepsi oral yang mengandung hormon estrogen atau progesteron maka terjadi peningkatan ekspresi reseptor beta estrogen $\beta$-ER. Kondisi ini berdampak pada pembentukan plak di pembuluh darah dan memicu risiko terjadinya aterosklerosis serta hipertropi jantung yang dapat memicu peningkatan tekanan darah (Böttner 
et al., 2013). Disisi lain, akseptor yang menggunakan kontrasepsi oral berisiko mengalami gangguan metabolisme lemak. Adanya gangguan tersebut menyebabkan terbentuknya plak yang akhirnya mempersempit pembuluh darah dan sirkulasi darah menjadi terhambat. Hal ini memicu terjadinya peningkatan tekanan darah, hipertensi. Selain itu, penumpukkan lemak di pembuluh darah arteri juga dapat menyebabkan terjadinya arterosklerosis (Boldo \& White, 2011; Katzung et al., 2014).

Tabel 2. Risiko Kejadian Hipertensi Berdasarkan Perbedaan Usia Pada Akseptor Kontrasepsi Oral di Puskesmas Perumnas II Kota Pontianak Selama Tahun 2017-2019 (N=75). Keterangan: $\mathrm{ref}=$ reference (pembanding); $\mathrm{RR}=$ relative risk; $\mathrm{CI}=$ confidence interval .

\begin{tabular}{|c|c|c|c|c|c|c|c|}
\hline \multirow{3}{*}{ Usia } & \multicolumn{4}{|c|}{ Risiko Kejadian Hipertensi } & \multirow[t]{3}{*}{ Nilai $\mathbf{P}$} & \multirow[t]{3}{*}{$\mathbf{R R}$} & \multirow{3}{*}{$\begin{array}{c}\text { CI 95\% } \\
\text { (lower-upper) }\end{array}$} \\
\hline & \multicolumn{2}{|c|}{$\mathbf{Y a}$} & \multicolumn{2}{|c|}{ Tidak } & & & \\
\hline & $\mathbf{n}$ & $\%$ & $\mathbf{N}$ & $\%$ & & & \\
\hline$>30$ tahun & 17 & 36,2 & 30 & 63,8 & 0,016 & ref & \\
\hline$\leq 30$ tahun & 3 & 10,7 & 25 & 89,3 & & 3,376 & $1,085-10,50$ \\
\hline
\end{tabular}

Penelitian ini juga mengkaji kesintasan penggunaan kontrasepsi oral baik pada kelompok akseptor yang berusia $>30$ tahun maupun kelompok akseptor yang berusia $\leq 30$ tahun. Dari Gambar 1 terlihat bahwa terdapat perbedaan kejadian hipertensi pada kelompok usia $>30$ tahun dibandingkan dengan kelompok usia $\leq 30$ tahun. Perbedaan kedua kelompok secara statistik bermakna signifikan ( $\log r a n k=5,98 ; \quad p=0,014)$. Laju kejadian hipertensi pada kelompok akseptor dengan usia > 30 tahun lebih cepat 4,045 kali dibandingkan dengan kelompok akseptor yang berusia $\leq 30$ tahun $(H R=4,045 ;$ CI95\%=1,18-13,88).

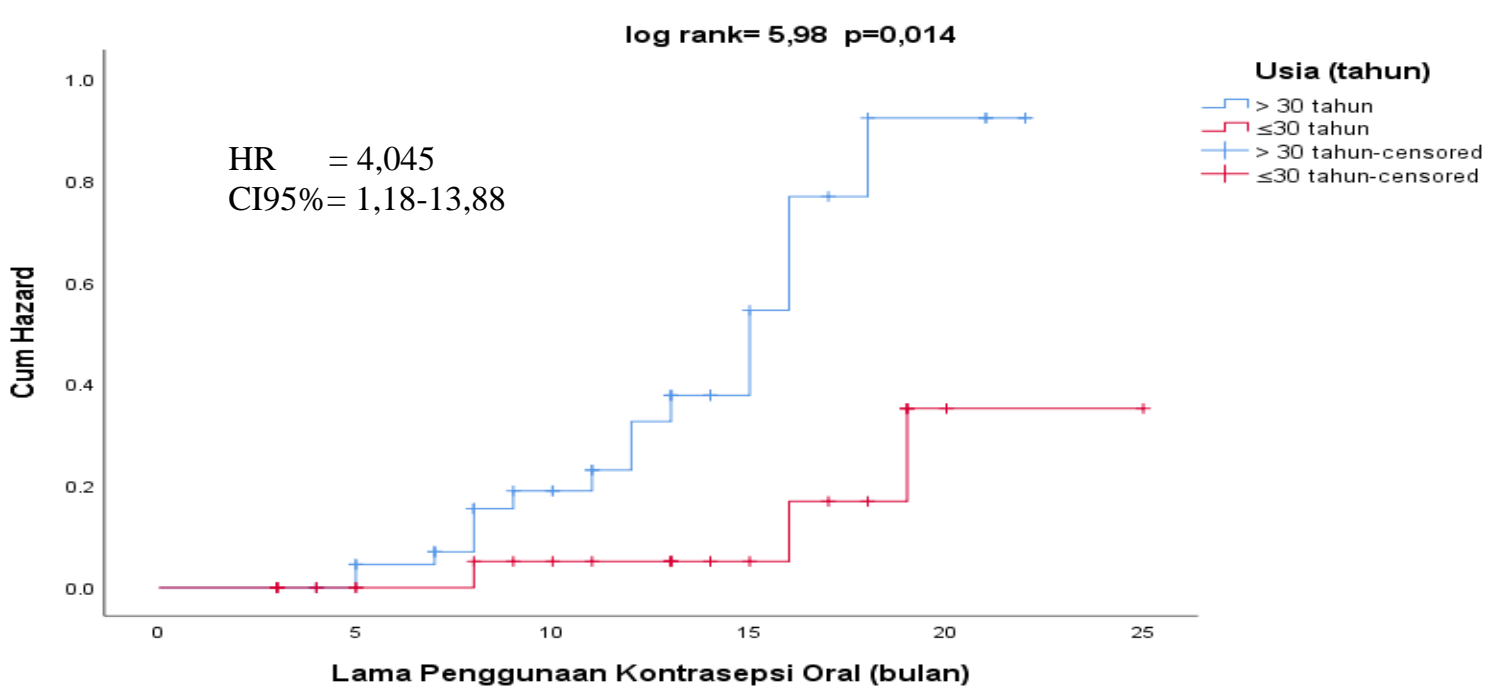

Gambar 1. Laju Kejadian Hipertensi Berdasarkan Perbedaan Kelompok Usia Akseptor Kontrasepsi Oral di Puskesmas Perumnas II Kota Pontianak selama Tahun 2017-2019. Keterangan: $\mathrm{HR}=$ hazard ratio $; \mathrm{CI}=$ confidence interval.

\subsection{Perbedaan Tekanan Darah Berdasarkan Perbedaan Kelompok Usia Akseptor Kontrasepsi Oral}

Sebelum dilakukan analisis uji t dilakukan analisis normalitas data dengan uji ShapiroWilk. Dari hasil uji normalitas diperoleh data terdistribusi normal $(\mathrm{p}<0,05)$. Selanjutnya, 
analisis uji t dilakukan untuk melihat perbedaan tekanan darah sistolik (TDS) dan tekanan darah diastolik (TDD) berdasarkan perbedaan kelompok usia. Tampak pada Tabel 3 bahwa akseptor berusia > 30 tahun mengalami peningkatan TDS dari $119,89 \pm 12,71 \mathrm{mmHg}$ menjadi 130,90 $\pm 13,56 \mathrm{mmHg}$ sedangkan TDD dari 76,06 $\pm 9,12 \mathrm{mmHg}$ menjadi $84,29 \pm 10,75 \mathrm{mmHg}$. Dari data tersebut menunjukkan akseptor $>30$ tahun sudah mulai mengalami pre hipertensi. Berbeda halnya dengan akseptor dari kelompok usia $\leq 30$ tahun juga mengalami peningkatan TDS dari 117,39 $\pm 11,18 \mathrm{mmHg}$ menjadi 121,02 $\pm 12,18 \mathrm{mmHg}$, sedangkan TDD dari $74,75 \pm 7,23 \mathrm{mmHg}$ menjadi $78,94 \pm 8,95 \mathrm{mmHg}$. Kelompok usia $\leq 30$ tahun menunjukkan TDS/TDD dalam kondisi nomal. Perbedaan tekanan darah dari perbedaan dua kelompok usia tersebut bermakna signifikan dimana nilai $\mathrm{p}<0,05$. Artinya, ada hubungan perbedaan peningkatan teknanan darah dengan perbedaan kelompok usia akseptor yang menggunakan kontrasepsi oral. Hal ini sejalan dengan penelitian Haroon yang menyebutkan bahwa usia berhubungan dengan peningkatan tekanan darah $(\mathrm{P}<0,05)$ (Haroon \& Naveed, 2014). Usia 3041 tahun cenderung mengalami peningkatan tekanan darah sebesar $30 \mathrm{mmHg}$ (Tanti et a., 2013). Hasil penelitian Rafia menunjukkan terjadi peningkatan tekanan darah dari 106/71 mmHg menjadi 130/80 mmHg setelah menggunakan kontrasepsi oral (Rafia et al., 2016).

Tabel 3. Perbedaan Tekanan Darah Berdasarkan Perbedaan Kelompok Usia Akseptor Kontrasepsi Oral di Puskesmas Perumnas II Kota Pontianak selama Tahun 2017-2019 $(\mathrm{N}=75)$. Keterangan: TDS = tekanan darah sistolik; TDD = tekanan darah diastolik; * $=$ berbeda signifikan.

\begin{tabular}{|c|c|c|c|c|c|c|}
\hline \multirow{2}{*}{ Usia } & \multicolumn{2}{|c|}{$\begin{array}{c}\text { Rata-rata TDS } \\
(\mathrm{mmHg})\end{array}$} & \multirow{2}{*}{$\begin{array}{c}\text { Nilai } \\
\mathbf{p}\end{array}$} & \multicolumn{2}{|c|}{$\begin{array}{c}\text { Rata-rata TDD } \\
(\mathrm{mmHg})\end{array}$} & \multirow{2}{*}{$\begin{array}{c}\text { Nilai } \\
\mathbf{p}\end{array}$} \\
\hline & Awal & Akhir & & Awal & Akhir & \\
\hline$>30$ tahun & $119,89 \pm 12,71$ & $130,90 \pm 13,56$ & $0,001^{*}$ & $76,06 \pm 9,12$ & $84,29 \pm 10,75$ & $0,001^{*}$ \\
\hline$\leq 30$ tahun & $117,39 \pm 11,18$ & $121,02 \pm 12,18$ & $0,018^{*}$ & $74,75 \pm 7,23$ & $78,94 \pm 8,95$ & $0,003^{*}$ \\
\hline
\end{tabular}

\section{Kesimpulan}

Akseptor yang berusia > 30 tahun memiliki risiko 3,376 kali lebih besar mengalami kejadian hipertensi dibandingkan dengan akseptor yang berusia $\leq 30$ tahun. Perbedaan kejadian hipertensi diantara dua kelompok secara statistik bermakna signifikan $(p=0,016 ; R R=3,376$; $C I 95 \%=1,085-10,50)$. Laju kejadian hipertensi pada kelompok akseptor dengan usia $>30$ tahun lebih cepat 4,045 kali dibandingkan dengan kelompok akseptor yang berusia $\leq 30$ tahun $(H R=4,045 ; C I 95 \%=1,18-13,88)$.

\section{Ucapan Terima Kasih}

Terima kasih kami sampaikan kepada Fakultas Kedokteran Universitas Tanjungpura dan Puskesmas Perumnas II Kota Pontianak yang telah membantu dalam pelaksanaan penelitian ini. 


\section{Deklarasi Konflik Kepentingan}

Semua penulis menyatakan tidak ada konflik kepentingan terhadap naskah ini.

\section{Daftar Pustaka}

Artiyaningrum, B. (2015). Faktor-faktor yang berhubungan dengan kejadian hipertensi tidak terkendali pada penderita yang melakukan pemeriksaan rutin di Puskesmas Kedungmundu Kota Semarang. Universitas Negeri Semarang.

Azima, S., dan Mousavi, S. (2017). Oral contraceptive pills use and hypertension. Int. J. Pharm. Sci. Invent, 6(1): pp.47-49.

BKKBN, 2018. Jurnal Keluarga Informasi Kependudukan, KB dan Pembangunan Keluarga. Jakarta, BKKBN.

Boldo, A., dan White, W.B. (2011). Blood pressure effects of the oral contraceptive and postmenopausal hormone therapies. Endocrinol Metab Clin N Am, 40: pp.419-432. 10.1016/j.ecl.2011.01.008

Böttner, M, Thelen, P., dan Jarry, H. (2013). Estrogen receptor beta: Tissue distribution and the still largely enigmatic physiological function. J. Steroid Biochem. Mol. Biol, pp.1-6. 10.1016/j.jsbmb.2013.03.003

Goel, M, Khanna, P., dan Kishore, J. (2010). Understanding survival analysis: Kaplan-Meier estimate. Int J Ayurveda Res, 4: pp.274-278. 10.4103/0974-7788.76794

Haroon, S., dan Naveed, A.K. (2014). Effect of hormonal contraceptives on serum electrolytes and blood pressure. J. Postgrad. Med. Inst, 28: pp.409-413.

Harvey, R.E, Coffman, K.E., dan Miller, V.M. (2016). Women-specific factors to consider in risk, diagnosis and treatment of cardiovascular disease Ronée. Womens Heal. (l. Engl), 11: pp.239-257. 10.2217/whe.14.64.Women-specific

Katzung, B.G, Masters, S.B., dan Trevor, A.J. (2014). Farmakologi Dasar \& Klinik, 12th ed. Jakarta, Penerbit Buku Kedokteran EGC.

Kementerian Kesehatan Republik Indonesia. (2013). Hasil Riset Kesehatan Dasar (RISKESDAS). Jakarta, Kementerian Kesehatan Republik Indonesia.

Kementerian Kesehatan Republik Indonesia. (2018). Data dan Informasi Profil Kesehatan Indonesia 2018. Jakarta, Kementerian Kesehatan Republik Indonesia.

Kusuma, I.Y., dan Kusnandar A. (2020). Evaluasi persepsi interprofessional education dan efektivitasnya pada tingkat pengetahuan tenaga kesehatan tentang $\mathrm{kb}$ oral dan suntik di Kota Bandung. JPSCR: Journal of Pharmaceutical Science and Clinical Research, 1: pp.70-83.

Mekonnen, T.T, Woldeyohannes, S.M., dan Yigzaw, T. (2015). Contraceptive use in women with hypertension and diabetes : cross-sectional study in northwest. Int. J. Women's Heal, 7: pp.957-964. 10.2147/IJWH.S90741

Nurmaghfirawati, A. (2016). Hubungan penggunaan kontrasepsi hormonal terhadap kejadian hipertensi pada wanita usia subur (wus) di Puskesmas Kassi-Kassi Kota Makassar tahun 2016. Fakultas Ilmu Kesehatan UIN Alauddin Makassar. 
Olatunji, L.A., dan Soladoye, A.O. (2008). Oral contraceptive-induced high blood pressure is prevented by renin-angiotensin suppression in female rats but not by sympathetic nervous system blockade. Indian J. Exp. Biol, 46: pp.749-754.

Pangaribuan, L., dan Dina, B.L. (2015). Hubungan penggunaan kontrasepsi pil dengan kejadian hipertensi pada wanita usia 15-49 tahun di Indonesia tahun 2013 (analisis data riskesdas 2013). Media Litbangkes, 25: pp.1-7.

Rafia, A, Ramadhan, A., dan Rusli, R. (2016). Pengaruh penggunaan kontrasepsi hormopnal terhadap tekanan darah pada akseptor $k b$ di Kota Samarinda. Universitas Mulawarman, Samarinda, pp. 35-41.

Rich, JT., Neely, J.G., Paniello, R.C., Voelker, C.C.J., Nussenbaum, B, Wang, E. (2010). A Practical Guide to Understanding Kaplan-Meier Curves. Otolaryngol. Neck Surg, 143: pp.331-336. 10.1016/j.otohns.2010.05.007

Sepriandi, Sri, M., dan Susmini. (2017). Hipertensi pada wanita pasangan usia subur dengan lama penggunaan pil kb. Nurs. News (Meriden), 2: pp.823-832.

Septya, S.K, Billy, J.K., dan Nancy, S.H.M. (2014). Hubungan antara penggunaan kontrasepsi pil dengan hipertensi pada wanita usia subur di Puskesmas Bahu Kota Manado, Universitas Samratulangi.

Sudayasa, I.P, Yasin, E.R.S., dan Lianawati. (2017). Hubungan lama pemakaian kontrasepsi oral dengan hipertensi, in: Seminar Nasional Riset Kuantitatif Terapan 2017 (pp. 4650). Kendari, Universitas Halu Oleo.

Tanti, A.S, Alfiana, M., dan Arif R.H. (2013). Pengaruh pemakaian kontrasepsi terhadap peningkatan tekanan darah wanita di Puskesmas Wonogiri. J. Farm. Klin. Indones, 2: pp.61-69. 10.15416/ijcp.

White, K, Potter, J.E, Hopkins, K, Amastae, J., dan Grossman, D. (2015). Hypertension among oral contraceptive users in El Paso, Texas. J Heal. Care Poor Underserved, 24: pp.1511-1521. 10.1353/hpu.2013.0172.

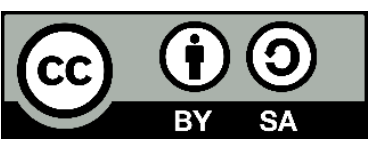

C 2021 by the authors. Submitted for possible open access publication under the terms and conditions of the Creative Commons Attribution-ShareAlike 4.0 International (CC BY-SA 4.0) license (https://creativecommons.org/licenses/by-sa/4.0/). 